\title{
KNOWLEDGE, ATTITUDE AND PRACTICE OF HEALTHCARE WORKERS TOWARDS NOVEL CORONA VIRUS (COVID-19) IN JUGAL HOSPITAL, HARARI REGIONAL STATE, ETHIOPIA
}

\author{
Arif H. Jamie \\ Harar Health Science College, Department of Pediatrics Nursing, East Ethiopia, Ethiopia
}

Received: 4 June 2020 | Accepted: 12 August 2020

DOI: https://dx.doi.org/10.36685/phi.v6i3.341

\author{
Correspondence: \\ Arif H. Jamie \\ Harar Health Science College, Department of Pediatrics Nursing, East Ethiopia, Ethiopia \\ Email: arifhussen.ah@gmail.com
}

Copyright: (C) 2020 the author(s). This is an open-access article distributed under the terms of the Creative Commons Attribution Non-Commercial License, which permits unrestricted non-commercial use, distribution, and reproduction in any medium, provided the original work is properly cited.

\begin{abstract}
Introduction: Coronavirus (CoVs) belong to the subfamily Corona virinae in the family of Corona viridae of the order Nido virales, and this sub family includes four genera: Alpha corona virus, Beta corona virus, Gamma corona virus and Delta corona virus. The genome of CoVs is a single-stranded positive-sense RNA (+ssRNA) $(\sim 30 \mathrm{~kb})$ with $5^{\prime}$-cap structure and $3^{\prime}$-poly-A tail.

Method: Cross sectional quantitative study was conducted from February to March 2020 at Jugal Hospital, Harar, Ethiopia, which is found $525 \mathrm{~km}$ to East of Addis Ababa. Data were collected using a self-administered questionnaire. Data were analyzed using a descriptive statistic using SPSS version 20.

Result: Majority of the staffs had a good knowledge about COVID-19, almost all 201(97.10\%) answered they are not ready to give care for a patient who is positive for COVID-19 and only $7(3.38 \%)$ of the participants answered that there is enough soap and water to wash hand, hand sanitizers and personal protective equipment materials.

Conclusion: The findings of this study showed that majority of the respondents have adequate knowledge, attitude and practice about COVID-19. Nevertheless, greater than $95 \%$ of respondents said that they are not ready to give care for a patient who is positive for COVID-19, there is no enough soap and water to wash hand, hand sanitizers and Personal Protective Equipment materials like mask, glove and they are afraid that one of their family members can get infection.
\end{abstract}

Keywords: COVID-19, knowledge, attitude, practice, health care workers

\section{INTRODUCTION}

Corona virus disease 2019 (abbreviated "COVID19 ") is an emerging respiratory disease that is caused by a novel corona virus and was first detected in December 2019 in Wuhan, China. The disease is highly infectious and its main clinical symptoms include fever, dry cough, fatigue, myalgia, and dyspnea (Nishiura et al., 2020).
CoVs belong to the subfamily Corona virinae in the family of Corona viridae of the order Nido virales, and this sub family includes four genera: Alpha corona virus, Beta corona virus, Gamma corona virus and Delta corona virus. The genome of CoVs is a single-stranded positive-sense RNA (+ssRNA) $(\sim 30 \mathrm{~kb})$ with $5^{\prime}$-cap structure and $3^{\prime}$ poly-A tail ( Snijder et al., 2006). Originally, the 
disease is classified under zoonotic diseases; the pathogen can be transmitted from animal to human and human to human (Bai et al., 2020). It is transmission from human to human is through droplet, feco-oral, and direct contact and has an incubation period of 2-14 days (World Health Organization, 2020b). It causes illness ranging from simplest of common cold to severe acute respiratory syndrome (SARS) (Yin \& Wunderink, 2018).

The World Health Organization (WHO) declared COVID-19 a public health emergency of international concern On 30 January 2020, (PHEIC) (Eurosurveillance Editorial Team, 2020). The ongoing COVID-19 epidemic has spread very quickly, and by April 04, 2020, the virus had reached 205 countries altogether, resulting in 1,141,425 laboratory-confirmed infections and 61,239 total deaths, 236,528 recovered, 842,882 active case in which 803,215 (95\%) in mild condition and 39,667 (5\%) serious or critical condition, whereas in Ethiopia, total case 38 , recovered 4, active case 34 in which 1 case is in Serious or Critical Condition (World Health Organization, 2020c).

There is a concern about possible increased numbers of human infections and deaths. By the end of January, the WHO and Centers for Disease Control and Prevention (CDC) had published recommendations for the prevention and control of COVID- 19 for HCWs (Centers for Disease Control and Prevention, 2020; World Health Organization, 2020a).

Health care providers in hospitals are at risk of infection through occupational exposure to suspected cases. They are also expected to participate in health education activities on the infection, particularly if they have relevant information which can be given to patients, and through them, to their families and members of the community. It is important therefore that they have adequate and correct knowledge, attitudes and practices (KAP) towards $\mathrm{CoV}$.

The aim of this study therefore was to evaluate KAP towards $\mathrm{CoV}$ among health care providers in Jugal hospitals in Harari region.

\section{METHOD}

\section{Study Setting and Participants}

The institutional cross-sectional quantitative study was conducted from February to March 2020 at Jugal hospital, Harar, Ethiopia, which is found $525 \mathrm{~km}$ to East of Addis Ababa. The hospital has a total of 220 health professionals.

\section{Instruments}

Data were collected using a self-administered questionnaire. Construction, the questionnaire included: 16 questions on knowledge, 14 questions on attitudes and 9 questions on practices.

\section{Data Analysis}

For data processing and analysis, SPSS version 20 was used. Data was checked for completeness and consistency; coded data was entered into computer programs after the required cleaning was done descriptive analyses was performed.

\section{Ethical Consideration}

The study was conducted among all health professionals in Jugal Hospital. Ethical clearance was obtained from Harar Health Science College Institutional Review Board (IRB) (Ref.no.HHSC09/2020). Before the staring of the field work, consent was obtained from both administrative body and respondent.

\section{RESULTS}

Socio-Demographic Characteristics of the Participants

Among a total of 220 health care workers, 207 of whom completed the study questionnaire and participated in the study which makes response rate of $94 \%, 120(57.97 \%)$ of the participants were female, around half of the participants $101(48.79 \%)$ were age group of $25-34$ years, regarding occupation more than half $118(57 \%)$ were nurses and regarding Attending training/seminar about Novel Corona virus only $5(2.42 \%)$ participated (See Table 1). 
Table 1 Socio Demographic Characteristics of Study Participants

\begin{tabular}{llcc}
\hline Variable & Option & Frequency & Percentage \\
\hline Sex & Male & 87 & 42.03 \\
& Female & 120 & 57.97 \\
\hline Age & 25 & 34 & 16.43 \\
& $25-34$ & 101 & 48.79 \\
& $35-44$ & 42 & 20.29 \\
& $45-54$ & 27 & 13.04 \\
& $55+$ & 3 & 1.45 \\
\hline Occupation & Doctors & 18 & 8.70 \\
& Pharmacists \& druggist & 18 & 8.70 \\
& Midwifery & 15 & 7.25 \\
& Nurse & 118 & 57.00 \\
& Lab-technicians & 17 & 8.2 \\
& X-ray technicians & 9 & 4.35 \\
& Anesthetist & 7 & 3.38 \\
& Others & 5 & 2.42 \\
\hline Do you attend training/seminar & Yes & 202 & 97.58 \\
about Novel Corona virus & No & 5 & 2.42 \\
\hline
\end{tabular}

Knowledge about COVID-19

All 207 (100\%) of participants answered that they heard about COVID-19, all of them agreed that sick patients should share their recent travel history with healthcare providers. Regarding knowledge about the origin of the disease, the disease is originated from bats were answered by $51(24.64 \%)$ 'no' and 'I do not know' by $9(4.35 \%)$. In regards to sign and symptoms of a disease, 207(100\%) of them answered headache, fever, cough, sore throat, and flu are symptoms of COVID-19. In mode of transmission, only 57(27.54\%) answers COVID-19 is transmitted through air, contact and fecal-oral routes. In the management of the disease, $192(92.75 \%)$ answers that supportive care is the current treatment for COVID-19 (See Table 2).

Table 2 Knowledge about Novel Corona Virus (COVID-19) Among Healthcare Workers at Jugal hospital, Harari Regional State, Harar, Ethiopia, 2020

\begin{tabular}{lccc}
\hline & Yes & No & I do not know \\
\hline Do you hear about COVID-19 & $207(100.00 \%)$ & $0(0.00 \%)$ & $0(0.00 \%)$ \\
\hline COVID-19 symptoms appear in 2-14 days & $201(97.10 \%)$ & $6(2.90 \%)$ & $0(0.00 \%)$ \\
\hline COVID-19 is fatal & $193(93.24 \%)$ & $7(3.38 \%)$ & $7(3.38 \%)$ \\
\hline Flu vaccinated is sufficient for preventing COVID-19 & $14(6.76 \%)$ & $197(95.17 \%)$ & $0(0.00 \%)$ \\
\hline $\begin{array}{l}\text { During the outbreak, eating well-cooked and safely handled meat is } \\
\text { safe }\end{array}$ & $191(92.27 \%)$ & $7(3.38 \%)$ & $9(4.35 \%)$ \\
\hline $\begin{array}{l}\text { Sick patients should share their recent travel history with healthcare } \\
\text { providers }\end{array}$ & $207(100.00 \%)$ & $0(0.00 \%)$ & $0(0.00 \%)$ \\
\hline $\begin{array}{l}\text { Disinfect equipment's and working area in wet souk at least once a } \\
\text { day }\end{array}$ & $207(100.00 \%)$ & $0(0.00 \%)$ & $0(0.00 \%)$ \\
\hline COVID-19 is thought to be originated from bats & $147(71.01 \%)$ & $51(24.64 \%)$ & $9(4.35 \%)$ \\
\hline COVID-19 is transmitted through air, contact, fecal-oral routes & $57(27.54 \%)$ & $133(64.25 \%)$ & $17(8.21 \%)$ \\
\hline $\begin{array}{l}\text { Headache, fever, cough, sore throat, and flu are symptoms of } \\
\text { COVID-19 }\end{array}$ & $207(100.00 \%)$ & $0(0.00 \%)$ & $0(0.00 \%)$ \\
\hline $\begin{array}{l}\text { COVID-19 leads to pneumonia, respiratory failure, and death } \\
\text { Supportive care is the current treatment for COVID-19 }\end{array}$ & $207(100.00 \%)$ & $0(0.00 \%)$ & $0(0.00 \%)$ \\
\hline $\begin{array}{l}\text { Hand hygiene, covering nose and mouth while coughing, and } \\
\text { avoiding sick contacts can help in the prevention of COVID-19 } \\
\text { transmission. }\end{array}$ & $207(100.00 \%)$ & $0(0.00 \%)$ & $0(0.00 \%)$ \\
\hline $\begin{array}{l}\text { Not all persons with COVID-2019 will develop to severe case. } \\
\text { Persons with COVID-19 cannot transmitted the virus to others } \\
\text { when a fever is not present }\end{array}$ & $147(71.01 \%)$ & $33(15.94 \%)$ & $27(13.04 \%)$ \\
\hline $\begin{array}{l}\text { It is not necessary for children and young adults to take measures } \\
\text { to prevent the infection by the COVID 19 virus }\end{array}$ & $198(95.65 \%)$ & $99(47.83 \%)$ & $7(3.38 \%)$ \\
\hline
\end{tabular}


Attitude towards COVID-19

In regards to staffs attitude towards COVID-19, all $207(100 \%)$ of them answered 'yes' for 'it is important to report a suspected case to health authorities', 'corona virus infection is preventable', 'schools \& work places should be closed during a corona virus epidemic', and 'people who have contact with someone infected with the COVID-19 virus should be immediately isolated in a proper place'. But the main issue which needs very attention is almost all 201(97.10\%) answered they are not ready to give care for a patient who is positive for COVID-19 (See Table 3).

Table 3 Attitude about Novel Corona Virus (COVID-19) among Healthcare Workers at Jugal hospital, Harari Regional State, Harar, Ethiopia, 2020

\begin{tabular}{lccc}
\hline & Yes & No & I do not know \\
\hline $\begin{array}{l}\text { It is important to report a suspected case to health } \\
\text { authorities }\end{array}$ & $207(100.00 \%)$ & $0(0.00 \%)$ & $0(0.00 \%)$ \\
\hline $\begin{array}{l}\text { It is important to use a face mask during working } \\
\text { hours }\end{array}$ & $207(100.00 \%)$ & $0(0.00 \%)$ & $0(0.00 \%)$ \\
\hline Corona virus infection can be treated at home & $0(0.00 \%)$ & $207(100.00 \%)$ & $0(0.00 \%)$ \\
\hline Corona virus infection is preventable & $207(100.00 \%)$ & $0(0.00 \%)$ & $0(0.00 \%)$ \\
\hline $\begin{array}{l}\text { You are afraid that one of your family members can } \\
\text { get infection }\end{array}$ & $191(92.27 \%)$ & $7(3.38 \%)$ & $9(4.35 \%)$ \\
\hline $\begin{array}{l}\text { You are afraid to go to public places in case you } \\
\text { might get infected }\end{array}$ & $147(71.01 \%)$ & $33(15.94 \%)$ & $27(13.04 \%)$ \\
\hline $\begin{array}{l}\text { Schools \& work places should be closed during a } \\
\text { corona virus epidemic }\end{array}$ & $207(100.00 \%)$ & $0(0.00 \%)$ & $0(0.00 \%)$ \\
\hline $\begin{array}{l}\text { Government institutions have the capability to } \\
\text { control an epidemic }\end{array}$ & $147(71.01 \%)$ & $51(24.64 \%)$ & $9(4.35 \%)$ \\
\hline $\begin{array}{l}\text { Health education has nothing to do with disease } \\
\text { prevention }\end{array}$ & $57(27.54 \%)$ & $133(64.25 \%)$ & $17(8.21 \%)$ \\
\hline $\begin{array}{l}\text { Handling corona virus-infected patient does not } \\
\text { threaten medical and paramedical staff }\end{array}$ & $207(100.00 \%)$ & $0(0.00 \%)$ & $0(0.00 \%)$ \\
\hline $\begin{array}{l}\text { To prevent the infection by COVID-19, individuals } \\
\text { should avoid going to crowded places such as train } \\
\text { stations and avoid taking public transportations. }\end{array}$ & $207(100.00 \%)$ & $0(0.00 \%)$ & $0(0.00 \%)$ \\
\hline $\begin{array}{l}\text { Isolation and treatment of people who are infected } \\
\text { with the COVID-19 virus are effective ways to } \\
\text { reduce the spread of the virus. }\end{array}$ & $192(92.75 \%)$ & $6(2.90 \%)$ & $9(4.35 \%)$ \\
$\begin{array}{l}\text { People who have contact with someone infected } \\
\text { with the COVID-19 virus should be immediately } \\
\text { isolated in a proper place. In general, the } \\
\text { observation period is } 14 \text { days. }\end{array}$ & $207(100.00 \%)$ & $0(0.00 \%)$ & $0(0.00 \%)$ \\
\hline $\begin{array}{l}\text { Are you ready to give care for a patient who is } \\
\text { positive for COVID-19? }\end{array}$ & $6(2.90 \%)$ & $201(97.10 \%)$ & $0(0.00 \%)$ \\
\hline
\end{tabular}

COVID 19 Prevention Practices

In regards to COVID 19 prevention practice, all of the participants $207(100 \%)$ reported that they wash their hands using soap and water continuously, cover their nose and mouth with a tissue while sneezing or coughing and avoid touching their eyes, nose or mouth. But an interesting issue is only $7(3.38 \%)$ of the participants answered that there is enough soap and water to wash hand, hand sanitizers and personal protective equipment materials like mask, glove apron, etc. (See Table 4).

Table 4 Practice about Novel corona virus (COVID-19) Among Healthcare Workers at Jugal Hospital, Harari Regional State, Harar, Ethiopia, 2020

\begin{tabular}{lccc}
\hline Practice questions & Yes & No & I do not know \\
\hline I use soap and water to wash my hands continuously & $207(100.00 \%)$ & $0(0.00 \%)$ & $0(0.00 \%)$ \\
\hline $\begin{array}{l}\text { I cover my nose and mouth with a tissue while sneezing or } \\
\text { coughing }\end{array}$ & $207(100.00 \%)$ & $0(0.00 \%)$ & $0(0.00 \%)$ \\
\hline I throw the used tissue in the trash & $207(100.00 \%)$ & $0(0.00 \%)$ & $0(0.00 \%)$ \\
\hline Avoid touching my eyes,nose or mouth as much as I can & $207(100.00 \%)$ & $0(0.00 \%)$ & $0(0.00 \%)$ \\
\hline I use face mask in crowds & $191(92.27 \%)$ & $7(3.38 \%)$ & $9(4.35 \%)$ \\
\hline
\end{tabular}


Table 4 (Cont.)

\begin{tabular}{lccc}
\hline I have healthy eating and lifestyle habits & $147(71.01 \%)$ & $9(4.35 \%)$ & $51(24.64 \%)$ \\
\hline I have educated clients about the disease & $74(27.54 \%)$ & $133(64.25 \%)$ & $0(0.00 \%)$ \\
\hline $\begin{array}{l}\text { Do you think that there is enough soap and water to wash } \\
\text { hand, hand sanitizers, PPE materials }\end{array}$ & $7(3.38 \%)$ & $191(92.27 \%)$ & $9(4.35 \%)$ \\
\hline
\end{tabular}

\section{DISCUSSION}

This study revealed that all respondents heard about COVID-19. This finding is more than study done in UAE which was $(97.8 \%)$ (Bhagavathula, Aldhaleei, Rahmani, Mahabadi, \& Bandari, 2020). In addition, all respondents responds that maintaining hand hygiene and covering the nose and mouth while coughing could help to prevent COVID-19 transmission which is higher than study done in UAE which was $(85.6 \%)$ (Bhagavathula et al., 2020).

In this study, all of the participants agreed that that COVID-19 could lead to pneumonia, respiratory failure, and death which is high compared to the study done in UAE which was (84\%) (Bhagavathula et al., 2020). Also, all participants agreed that sick patients should share their recent travel history which is high compared to the study done in UAE which was (92.7\%) (Bhagavathula et al., 2020).

All of the participants felt that washing hands with soap and water could help to prevent COVID-19 which is high compared to the study done in UAE which was (87\%). (Bhagavathula et al., 2020). $95.17 \%$ of the respondents respond that that flu vaccination is not sufficient to prevent COVID-19, which is high compared to the study done in UAE which was $(90.7 \%)$ (Bhagavathula et al., 2020).

This study revealed that $92.75 \%$ of the respondents respond that supportive care is the only treatment option that is currently available which is high compared to the study done in UAE which was $(83.2 \%)$ (Bhagavathula et al., 2020). Additionally, $92.75 \%$ of the respondents knew that symptoms appear in 2-14 days which is high compared to the study done in UAE which was (84.3\%) (Bhagavathula et al., 2020). This disparity could partly be attributed to the difference in the study time, the UAE study was done in beginning month of corona virus epidemic whereas this study done in late months after getting a lot of information regarding the diseases.

In this study, only (2.42\%) attend training/seminar about Novel Corona virus which is very low compared to study done in UAE which shows $44.1 \%$ of them had the opportunity to attend lectures/discussions about COVID-19 (Bhagavathula et al., 2020). This disparity could partly be attributed to the difference in socio economic status of the country to give lecture using video conferences and like.

\section{Limitations}

This study was conducted using a crosssectional study design, the study was subjected to recall bias because it was self-reported and it was dependent on the honest answer and recall ability of the participants. Since the disease is new, there are no many researches done in the topic. For discussion, only one research was obtained. Despite these limitations, the findings provide valuable information about the knowledge, attitude and practice of the staffs.

\section{CONCLUSION}

The finding of this study showed that majority of respondents have adequate knowledge, attitude and practice about COVID-19. Nevertheless, greater than $95 \%$ of respondents said that they are not ready to give care for a patient who is positive for COVID-19. The reason behind this is that there is no enough soap and water to wash hand, hand sanitizers and personal protective equipment materials like mask, glove and due to this they are afraid that one of their family members can get infection. The hospital must fulfill necessary personal protective equipment, hand washing materials and prepare seminar/lecture for all of the staffs and the Regional Health Bureau must prepare temporary residence to staffs specially who assigned in corona center not to contaminate their family members. 
Declaration of Conflict of Interests

The author would like to declare that no conflict of interests in this study.

Acknowledgment

The author would like to extend sincere thanks to Jugal hospital staffs for their cooperation to fill the questionnaire. The author would like to extend special thanks to Dr. Adila Jelaludin for collecting filled questionnaires.

Funding

No funding for this research.

\section{References}

Bai, Y., Yao, L., Wei, T., Tian, F., Jin, D.-Y., Chen, L., \& Wang, M. (2020). Presumed asymptomatic carrier transmission of COVID-19. JAMA, 323(14), 14061407.

Bhagavathula, A. S., Aldhaleei, W. A., Rahmani, J., Mahabadi, M. A., \& Bandari, D. K. (2020). Novel coronavirus (COVID-19) knowledge and perceptions: A survey on healthcare workers. MedRxiv. 20033381

Centers for Disease Control and Prevention. (2020). Update and interim guidelines on outbreak of 2019 Novel corona virus (2019-nCoV). Retrieved from https://emergency.cdc.gov/han/han00427.asp

Eurosurveillance Editorial Team. (2020). Note from the editors: World Health Organization declares novel coronavirus (2019-nCoV) sixth public health emergency of international concern. Eurosurveillance, 25(5), 200131e.
Nishiura, H., Jung, S.-m., Linton, N. M., Kinoshita, R., Yang, Y., Hayashi, K., . . . Akhmetzhanov, A. R. (2020). The extent of transmission of novel coronavirus in Wuhan, China, 2020. Journal of Clinical Medicine, 9(2), 330.

Snijder, E. J., Van Der Meer, Y., Zevenhoven-Dobbe, J., Onderwater, J. J., Van Der Meulen, J., Koerten, H. K., \& Mommaas, A. M. (2006). Ultrastructure and origin of membrane vesicles associated with the severe acute respiratory syndrome coronavirus replication complex. Journal of Virology, 80(12), 5927-5940.

World Health Organization. (2020a). Coronavirus disease 2019 (COVID-19): Situation report. Geneva: World Health Organization.

World Health Organization. (2020b). Infection prevention and control during health care when novel coronavirus (nCoV) infection is suspected: Interim guidance. Geneva: World Health Organization.

World Health Organization. (2020c). Novel Coronavirus (2019-nCoV): Situation report. Geneva: World Health Organization.

Yin, Y., \& Wunderink, R. G. (2018). MERS, SARS and other coronaviruses as causes of pneumonia. Respirology, 23(2), 130-137.

Cite this article as: Jamie, A.H. (2020). Knowledge, attitude and practice of healthcare workers towards Novel Corona Virus (COVID-19) in Jugal Hospital, Harari Regional State, Ethiopia. Public Health of Indonesia, 6(3), 72-77. https://dx.doi.org/10.36685/phi.v6i3.341 